\title{
Chemical Composition and Antimicrobial Activity of Essential Oil Extracted from Eucalyptus citriodora Leaf
}

\author{
Wimonrut Insuan and Thippayarat Chahomchuen* \\ Department of Veterinary Technology, Kasetsart University, Bangkok 10900, Thailand
}

Received: December 23, 2019 / Revised: February 14, 2020 / Accepted: February 25, 2020

\begin{abstract}
Eucalyptus oil is a rich source of bioactive compounds with a variety of biological activities and is widely used in traditional medicine. Eucalyptus citriodora is cultivated for the production of essential oils. However, the mode of antibacterial action of essential oils from $E$. citriodora is not well-known. This study aimed to determine the chemical components, microbial inhibitory effect, and mechanism of action of the essential oil from $E$. citriodora. The oil was extracted from $E$. citriodora leaves by hydro-distillation and the chemical components were analyzed using gas chromatography-mass spectrometry. The antibacterial activities of eucalyptus oil against gram-positive bacteria (Bacillus subtilis, Staphylococcus aureus, and Staphylococcus intermedius) and gram-negative bacteria (Escherichia coli and Pseudomonas aeruginosa) were screened by disc diffusion method and quantitative analysis was conducted by the microdilution method. The mechanism of action of the extracted essential oil was observed using SEM and analyzed by SDS-PAGE. The major components of $E$. citriodora oil were citronellal $(60.55 \pm 0.07 \%)$, followed by dl-isopulegol $(10.57 \pm$ $0.02 \%)$ and citronellol $(9.04 \pm 0.03 \%)$. The antibacterial screening indicated that $E$. citriodora oil exhibited prominent activity against all tested strains. The minimum inhibitory concentration (MIC) and minimum bactericidal concentration (MBC) against B. subtilis were $0.5 \%$ and $1.0 \%$, respectively. The MIC and MBC concentrations against $S$. aureus, $S$. intermedius, $E$. coli, and $P$. aeruginosa were $1 \%$ and $2 \%$, respectively. As observed by SEM, the antibacterial mechanism of $E$. citriodora oil involved cell wall damage; SDS-PAGE revealed decrease in protein bands compared to untreated bacteria. Thus, $E$. citriodora oil showed significant antimicrobial properties and caused cellular damage.
\end{abstract}

Keywords: Eucalyptus citriodora oil, antibacterial activity, Staphylococcus intermedius, Pseudomonas aeruginosa, mechanism

\section{Introduction}

Antibacterial resistance is a serious threat and a global public health's concern. Bacterial species such as Pseudomonas and Staphylococcus cause various diseases and are opportunistic pathogens with increasing antibiotic resistance. Pseudomonas aeruginosa is of concern as a multidrug-resistant strain via various mechanism including enzyme production, a multidrug efflux system and biofilm formation [1]. Furthermore, the

\section{*Corresponding author}

Tel: +662-579-8571, Fax: +662-579-8571

E-mail: cvttyr@ku.ac.th

(c) 2020, The Korean Society for Microbiology and Biotechnology major human pathogenic bacteria $P$. aerugionsa can also affect companion animals via its circulation in the human-animal-environment interface of a household [2, 3]. Staphylococcus intermedius is an important pathogen in animal species. It is the most frequent cause of canine skin and ear infections which can transmit to humans $[4,5]$. Therefore, $P$. aeruginosa and S. intermedius are high risk zoonosis bacteria with effective strategies to adapt and contaminate while also being a resistant agent against typical antibiotics. Finding new, effective antimicrobial agents derived from natural resources has gained high priority among strategies for antibiotic resistance. Plants and their bioactive components are considered as rich sources of antimicrobial properties, 
with different modes of actions [6, 7]. Eucalyptus is a plant in the Myrtaceae family, widely grown in tropical and subtropical regions including Thailand [8]. Essential oils extracted from eucalyptus exhibit various properties such as antioxidant, antibacterial, antifungal, anticancer and antiviral activities [9, 10]. Among the many species of eucalyptus, Eucalyptus citriodora is the most common that is cultivated for the extraction of essential oil because the leaves accumulate many secondary metabolites. Monoterpenoids (citrionellal and citrionellol) are reported as a major component in the essential oil of E. citriodora growing in Australia, Brazil, China, Colombia, the Democratic Republic of Congo, Egypt, India, Indonesia, Pakistan and Taiwan [11, 12]. E. citriodora oil has multiple applications due to its antioxidant, antibacterial and antifungal activities [13, 14]. However, differences in geographic location influence the chemical compositions as well as antimicrobial activities against pathogenic microorganisms [11, 15].

Therefore, the objectives of present study were to investigate the chemical compositions of essential oil extracted from E. citriodora cultivated in northern Thailand, and to evaluate the antibacterial properties and the possible mode of action against $S$. intermedius and $P$. aeruginosa through changes in their bacterial microstructure and bacterial whole-cell proteins. At the same time, additional information on antibacterial activity against three common pathogenic bacteria including, Bacillus subtilis, Staphylococcus aureus and Escherichia coli were also investigated.

\section{Materials and Methods}

\section{Preparation of volatile extract}

Fresh leaves were collected from a $E$. citriodora plantation of a company in Lampang province, northern Thailand at $18^{\circ} 22^{\prime} 12.3^{\prime \prime} \mathrm{N} 99^{\circ} 32^{\prime} 16.5^{\prime \prime} \mathrm{E}$ during September 2018. A fresh leaf sample was weighed, thoroughly washed to remove any dust and impurities and subjected to hydro-distillation for the complete extraction of the essential oil. Distillates of the essential oil were dried using anhydrous sodium sulfate (UNIVAR, Ajax Finechem, Australia) and then filtered and stored at $-20^{\circ} \mathrm{C}$ until further testing and analysis without further extraction.

\section{Analysis of volatile extract}

The volatile compounds were analyzed using gas chromatography-mass spectrometry (GC/MS). Identification of compounds was based on comparisons of the mass spectra with those of the NIST mass spectral library data standards of the GC/MS system. The gas chromatographic system was interfaced with a mass spectrometer (GC/MS-QP2010 Systems, Shimadzu, Japan) with ionization energy $70 \mathrm{eV}$; ionization mode EI and equipped with a ZB-Wax capillary column $(30 \mathrm{~m} \times 0.25 \mathrm{~mm}$, $0.25 \mathrm{~mm}$ film thickness; USA). Mass scanning was from 40 to 500 amu. Helium (purity 99.9999\%) was the carrier gas, at a flow rate of $1.4 \mathrm{ml} / \mathrm{min}$. The injector, GC/MS interface and ion source temperatures were $250^{\circ} \mathrm{C}$. The oven temperature was programmed from 60 to $230^{\circ} \mathrm{C}$ at $5^{\circ} \mathrm{C} / \mathrm{min}$. Oil samples $(0.1 \mu \mathrm{l})$ were injected neat using a 1:25 split ratio.

\section{Microbial strains and culture conditions}

Five strains of microorganisms were used, of which three were Gram-positive (B. subtilis TISTR1248, S. aureus ATCC25923, and S. intermedius ATCC29663) and two were Gram-negative (E. coli ATCC25922 and $P$. aeruginosa ATCC27853). All reference strains were obtained from the Department of Veterinary Technology, Kasetsart University, Bangkok, Thailand. Bacterial strains were grown on nutrient agar plates at $37^{\circ} \mathrm{C}$ and maintained on nutrient agar slant. For antibacterial assay, overnight culture was used as fresh inoculum (1\%) in $10 \mathrm{ml}$ of Mueller-Hilton $(\mathrm{MH})$ broth (HiMedia, India) and further incubated at $37^{\circ} \mathrm{C}$ for $4 \mathrm{~h}$ at $200 \mathrm{rpm}$ on an incubator shaker.

\section{Evaluation of antimicrobial activity of Eucalyptus citriodora oil}

The antimicrobial activity of Eucalyptus oil was determined using the agar disc diffusion method. Briefly, the cell suspension of microorganisms in $\mathrm{MH}$ broth was adjusted to 0.5 McFarland (DEN-1B; McFarland densitometer, Biosan, Latvia) to obtain approximately $4 \times 10^{8}$ $\mathrm{cfu} / \mathrm{ml}$ confirmed viable counts. The bacterial suspension was spread uniformly onto the surface of $\mathrm{MH}$ agar in a $9 \mathrm{~cm}$ diameter Petri dish using a sterile cotton swab. The surface of the medium was allowed to dry. Sterile filter paper discs (6 mm in diameter) impregnated with $2 \mu \mathrm{l}$ of 
Eucalyptus citriodora oil were then placed aseptically on the surface of these agar plates. The plates were incubated at $37^{\circ} \mathrm{C}$ for $16 \mathrm{~h}$. Enrofloxacin solution was prepared in dimethylsulfoxide (DMSO) (Merck, Germany), using $4 \mu \mathrm{g} /$ disc as the standard antibiotic. For the negative control, $5 \mu \mathrm{l} /$ disc DMSO was used. The diameters of inhibition zones (DIZ, disc diameter included) were measured and recorded in millimeters. The experiment was carried out in triplicate and the results were expressed as mean \pm standard deviations.

\section{Determination of minimum inhibitory concentration and minimum bactericidal concentration (MIC and MBC)}

The MICs and MBCs of E. citriodora oil were evaluated using the microdilution method in 96-well microplates [16]. All the tests described in this section were performed in $\mathrm{MH}$ broth. The cell suspensions of microorganisms were washed three times with $0.5 \% \mathrm{NaCl}$ and adjusted to an optical density of 0.1 at $600 \mathrm{~nm}$ (NanoDrop 2000c Spectrophotometer; Thermo Scientific, USA) to achieve a concentration of approximately $10^{7} \mathrm{cfu} / \mathrm{ml}$ (confirmed by colony counting); the cell suspension was further diluted to achieve a concentration of $10^{6} \mathrm{cfu} / \mathrm{ml}$. Then, $100 \mu \mathrm{l}$ of bacterial solution were dispensed into individual wells in a 96-well plate. Two-fold serial dilutions of the oil was made using concentrations ranging from $4 \%$ to $0.625 \%$ in consecutive wells to yield final cell plate volumes of $100 \mu \mathrm{l}$. As a negative control, $100 \mu \mathrm{l}$ of $\mathrm{MH}$ broth/well were used and the positive control use $100 \mu \mathrm{l}$ of the bacterial inoculum without the oil. The microplates were then incubated at $37^{\circ} \mathrm{C}$ for $24 \mathrm{~h}$. After incubation, the OD was measured using a microplate reader (iMark Microplate Reader, Bio-RAD, USA) at $595 \mathrm{~nm}$. The lowest dilution showing no visible growth was considered as the MIC. To confirm the MIC results, $5 \mu \mathrm{l}$ of resazurin indicator solution were added to each well and the color change was observed during further incubation at $37^{\circ} \mathrm{C}$ for $30 \mathrm{~min}$. Viable bacteria reduced the blue resazurin color to pink. The MIC was defined as the sample concentration that prevented the color change of the medium and exhibited complete inhibition of microbial growth. The MBC of the oil against the tested bacterial strains was also determined by spotting $5 \mu \mathrm{l}$ from the well corresponding to the MIC or higher concentrations on $\mathrm{MH}$ agar, with further incubation of the plates for $24 \mathrm{~h}$ at $37^{\circ} \mathrm{C}$. The $\mathrm{MBC}$ was the lowest con- centration where no growth on agar occurred.

\section{Scanning electron microscopy (SEM)}

SEM was performed according to Agizzio et al. [17] with some modifications. Overnight cultures of $S$. intermedius and $P$. aeruginosa were inoculated in $\mathrm{MH}$ broth and cultured at $37^{\circ} \mathrm{C}$ for $4 \mathrm{~h}$. Bacterial cells $(0.5$ McFarland turbidity standard) were treated with $E$. citriodora oil at $1 \mathrm{MIC}$ and with DMSO as the negative control; then, after being incubated at $37^{\circ} \mathrm{C}$ for 3,6 and $16 \mathrm{~h}$, the cells were harvested using centrifugation for $10 \mathrm{~min}$ at $5,000 \times \mathrm{g}$ at $4^{\circ} \mathrm{C}$, washed three times with phosphate buffer saline (PBS) (pH 7.2), and fixed in $2.5 \%(\mathrm{v} / \mathrm{v})$ glutaraldehyde overnight at $4{ }^{\circ} \mathrm{C}$. Following a brief rinse in PBS, cells were dehydrated in 30, 50, 70, 80, 90 and $100 \%$ ethanol for $10 \mathrm{~min}$ each, and then the ethanol was replaced by tertiary butyl alcohol. The cells were filter through the nylon membrane $(0.2 \mu \mathrm{m}, 47 \mathrm{~mm}$, Waters, USA) by the vacuum filtration and cut a small piece of membrane into a size of $0.5 \times 0.5 \mathrm{~cm}$ for SEM specimen, then were dried with $\mathrm{CO}_{2}$. The dried specimens were stuck on an aluminum stub by using a double side carbon tape and then coated with gold by using a gold sputter (Quorum, SC7620, England) for $2 \mathrm{~min}$. After that their morphologies were characterized by using scanning electron microscope (Quanta 450, FEI, USA).

\section{SDS-PAGE analysis}

The effects of $E$. citriodora oil on bacterial protein patterns were analyzed using sodium dodecyl sulfatepolyacrylamide gel electrophoresis (SDS-PAGE). Initially, overnight cultures of $S$. intermedius and $P$. aeruginosa were adjusted to a $0.5 \mathrm{McF}$ arland standard in MH broth. Then, $10 \mathrm{ml}$ of working cultures were treated with eucalyptus oil at the final concentration of $1 \mathrm{MIC}$ and cultured at $37^{\circ} \mathrm{C}$ with shaking at $200 \mathrm{rpm}$. The same procedures were performed for the untreated cells using DMSO as the control. After incubation periods of $3,6,9$ and $16 \mathrm{~h}, 5 \mathrm{ml}$ of each treated sample were collected using centrifugation at $10,000 \times g$ at $4^{\circ} \mathrm{C}$ for $10 \mathrm{~min}$ (Tomy-MX-307; Refrigerate centrifuge, USA) to obtain cell pellets. Each bacterial cell pellet was mixed with SDS-PAGE loading buffer $(50 \mu \mathrm{l})$, heated at $95{ }^{\circ} \mathrm{C}$ for $10 \mathrm{~min}$, and analyzed using SDS-PAGE with a $4 \%$ stacking gel and a 10\% separating gel (Bio-RAD). The protein bands were stained with Coomassie brilliant blue R-250 
(Bio-RAD).

\section{Statistical analysis}

Data points in all experiments were performed in triplicate to obtain valid statistical evaluation of the results. All results represented the mean \pm S.D.

\section{Results}

\section{Chemicals identified in the oil}

The essential oil isolated using hydrodistillation from the leaves of $E$. citriodora was a pale-yellow liquid. The chromatogram is shown in Fig. 1. It was possible to identify each compound of the $E$. citriodora oil (Table 1 ). The chromatographic analysis of the eucalyptus oil using GC-MS allowed the identification of 50 components representing $99.04 \%$ of the total oil content. The main components were citronellal $(60.55 \pm 0.07 \%)$ followed by dl-isopulegol (10.57 $\pm 0.02 \%$ ), citronellol (9.04 $\pm 0.03 \%$ ), (-)- $\beta$-pinene $(1.85 \pm 0.01 \%), \gamma$-terpinene $(1.87 \pm 0.00 \%)$, methyleugenol (1.47 $\pm 0.01 \%)$, eucalyptol (1.40 $\pm 0.00 \%)$, (+)-cis-p-menthane-3,8-diol (1.03 $\pm 0.00 \%)$ and citronellic acid $(0.95 \pm 0.01 \%)$.

\section{Disc diffusion assay}

As a screening test, the eucalyptus oil from citriodora leave extracts was examined for antibacterial activity using disc diffusion assay (Fig. 2). The antibacterial activity of $E$. citriodora oil according to the zone of inhibition ranged between $7.9 \pm 0.10$ and $17.3 \pm 0.75 \mathrm{~mm}$ as shown in Table 2. The maximum zone of inhibition was against $S$. intermedius $(17.3 \pm 0.75 \mathrm{~mm})$ followed by $B$. subtilis $(11.1 \pm 0.10 \mathrm{~mm}), P$. aeruginosa $(10.9 \pm 0.77 \mathrm{~mm})$, $S$. aureus $(8.8 \pm 0.25 \mathrm{~mm})$ and $E$. coli $(7.9 \pm 0.10 \mathrm{~mm})$, respectively. The positive control enrofloxacin $(5 \mu \mathrm{g})$ had zones of inhibition against $B$. subtilis $(31.6 \pm 0.50 \mathrm{~mm})$, E. coli $(25.7 \pm 0.57 \mathrm{~mm}), P$. aeruginosa $(25.7 \pm 0.28 \mathrm{~mm})$, $S$. aureus $(24.9 \pm 0.81 \mathrm{~mm})$ and $S$. intermedius $(23.3 \pm$ $1.8 \mathrm{~mm}$ ), respectively. Based on the results of the disc diffusion assay, the oil showed an antibacterial effect against all tested bacteria. E. citriodora oil was selected for further observation of the antibacterial activity using the broth dilution method for quantitative analysis.

\section{Effects of $E$. citriodora oil on antibacterial activity, MIC and MBC}

The antibacterial activity of the E. citriodora oil extract was evaluated by determining MICs and MBCs to five reference strains shown in Table 3. The MIC and $\mathrm{MBC}$ values against B. subtilis were $0.5 \%(\mathrm{v} / \mathrm{v})$ and $2 \%$ (v/v), respectively. The MIC and MBC values for $S$. aureus, $S$. intermedius, $E$. coli and $P$. aeruginosa were all the same at $1 \%(\mathrm{v} / \mathrm{v})$ and $2 \%(\mathrm{v} / \mathrm{v})$, respectively. These results indicated that $E$. citriodora oil had potential antibacterial activity against the tested strains.

\section{Effects of $E$. citriodora oil on the structure of bacterial cells based on SEM analysis}

To observe morphology of bacterial cells after treated with $E$. citriodora oil used SEM. The mode of action of $E$.

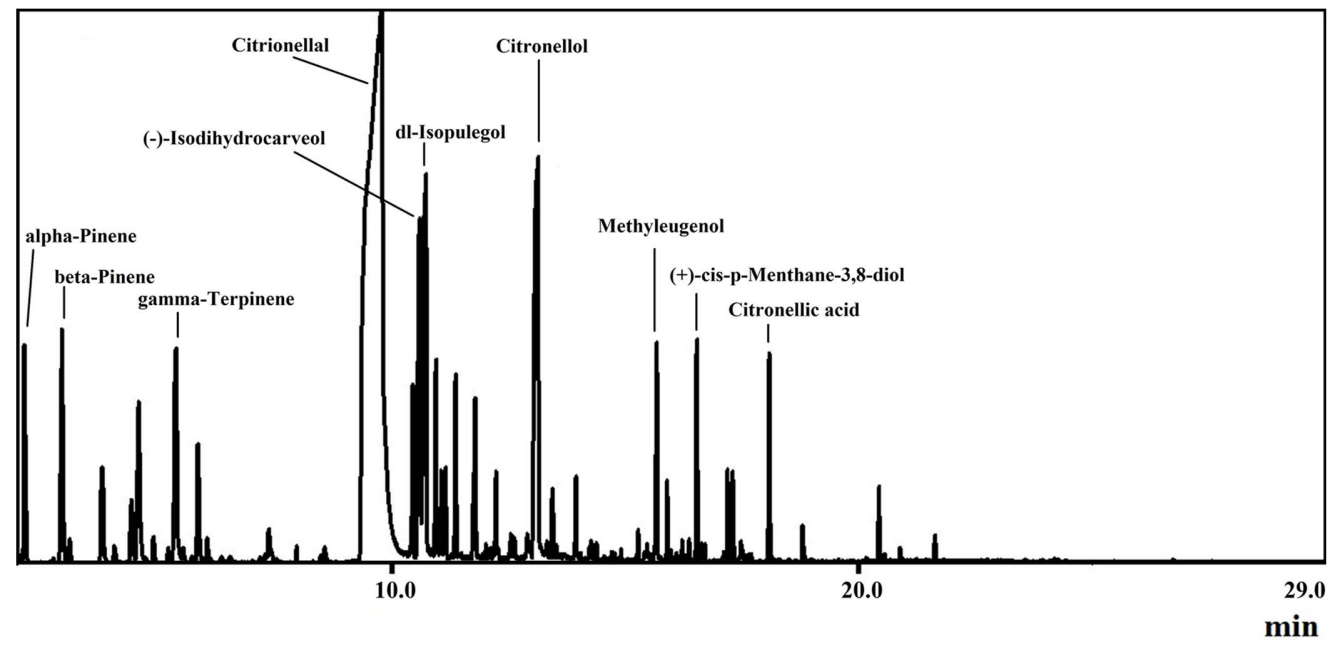

Fig. 1. GC/MS chromatogram of Eucalyptus citriodora oil. 
Table 1. Chemical compositions of Eucalyptus citriodora oil.

\begin{tabular}{|c|c|c|c|c|}
\hline $\operatorname{tr}(\min )$ & $\%$ Area* & Chemical compounds & Chemical formula & M.W. \\
\hline 2.956 & $1.85 \pm 0.01$ & (-)-beta-Pinene & $\mathrm{C}_{10} \mathrm{H}_{16}$ & 136.23 \\
\hline 3.13 & $0.11 \pm 0.00$ & alpha-Sabinene & $\mathrm{C}_{10} \mathrm{H}_{16}$ & 136.23 \\
\hline 3.828 & $0.72 \pm 0.00$ & alpha-Phellandrene & $\mathrm{C}_{10} \mathrm{H}_{16}$ & 136.23 \\
\hline 4.096 & $0.12 \pm 0.00$ & alpha-Terpinene & $\mathrm{C}_{10} \mathrm{H}_{16}$ & 136.23 \\
\hline 4.459 & $0.48 \pm 0.00$ & D-Limonene & $\mathrm{C}_{10} \mathrm{H}_{16}$ & 136.23 \\
\hline 4.597 & $1.40 \pm 0.00$ & Eucalyptol & $\mathrm{C}_{10} \mathrm{H}_{18} \mathrm{O}$ & 154.25 \\
\hline 4.913 & $0.11 \pm 0.00$ & 2-Hexenal & $\mathrm{C}_{6} \mathrm{H}_{10} \mathrm{O}$ & 98.14 \\
\hline 5.242 & $0.10 \pm 0.00$ & alpha-Pinene & $\mathrm{C}_{10} \mathrm{H}_{16}$ & 136.23 \\
\hline 5.392 & $1.87 \pm 0.00$ & gamma-Terpinene & $\mathrm{C}_{10} \mathrm{H}_{16}$ & 136.23 \\
\hline 5.872 & $0.81 \pm 0.00$ & o-Cymene & $\mathrm{C}_{10} \mathrm{H}_{14}$ & 134.21 \\
\hline 6.076 & $0.16 \pm 0.00$ & 4-Carene & $\mathrm{C}_{10} \mathrm{H}_{16}$ & 136.23 \\
\hline 7.385 & $0.24 \pm 0.00$ & Melonal & $\mathrm{C}_{9} \mathrm{H}_{16} \mathrm{O}$ & 140.22 \\
\hline 8.554 & $0.10 \pm 0.00$ & 1-methoxyethylcyclohexane & $\mathrm{C}_{9} \mathrm{H}_{18} \mathrm{O}$ & 142.24 \\
\hline 9.588 & $60.55 \pm 0.07$ & Citronellal & $\mathrm{C}_{10} \mathrm{H}_{18} \mathrm{O}$ & 154.25 \\
\hline 10.384 & $0.76 \pm 0.00$ & Linalool & $\mathrm{C}_{10} \mathrm{H}_{18} \mathrm{O}$ & 154.25 \\
\hline 10.53 & $3.60 \pm 0.01$ & dl-Isopulegol & $\mathrm{C}_{10} \mathrm{H}_{18} \mathrm{O}$ & 154.25 \\
\hline 10.648 & $6.97 \pm 0.02$ & dl-lsopulegol & $\mathrm{C}_{10} \mathrm{H}_{18} \mathrm{O}$ & 154.25 \\
\hline 10.896 & $0.93 \pm 0.00$ & Caryophyllene & $\mathrm{C}_{15} \mathrm{H}_{24}$ & 204.36 \\
\hline 11.03 & $0.35 \pm 0.00$ & Terpene-4-ol & $\mathrm{C}_{10} \mathrm{H}_{18} \mathrm{O}$ & 154.25 \\
\hline 11.118 & $0.52 \pm 0.00$ & 4-Menthen-8-ol & $\mathrm{C}_{10} \mathrm{H}_{18} \mathrm{O}$ & 154.25 \\
\hline 11.328 & $0.89 \pm 0.00$ & Neo-isoisopulegol & $\mathrm{C}_{10} \mathrm{H}_{18} \mathrm{O}$ & 154.25 \\
\hline 11.719 & $0.22 \pm 0.00$ & Melonol & $\mathrm{C}_{9} \mathrm{H}_{18} \mathrm{O}$ & 142.24 \\
\hline 11.779 & $0.69 \pm 0.01$ & Citronellol acetate & $\mathrm{C}_{12} \mathrm{H}_{22} \mathrm{O}_{2}$ & 198.30 \\
\hline 12.211 & $0.36 \pm 0.00$ & L-alpha-Terpineol & $\mathrm{C}_{10} \mathrm{H}_{18} \mathrm{O}$ & 154.25 \\
\hline 12.906 & $0.10 \pm 0.00$ & Geranyl acetate & $\mathrm{C}_{12} \mathrm{H}_{20} \mathrm{O}_{2}$ & 196.29 \\
\hline 13.07 & $9.04 \pm 0.03$ & Citronellol & $\mathrm{C}_{10} \mathrm{H}_{20} \mathrm{O}$ & 156.27 \\
\hline 13.419 & $0.23 \pm 0.00$ & Nerol & $\mathrm{C}_{10} \mathrm{H}_{18} \mathrm{O}$ & 154.25 \\
\hline 13.929 & $0.29 \pm 0.00$ & Geraniol & $\mathrm{C}_{10} \mathrm{H}_{18} \mathrm{O}$ & 154.25 \\
\hline 15.282 & $0.11 \pm 0.00$ & Caryophyllene oxide & $\mathrm{C}_{15} \mathrm{H}_{24} \mathrm{O}$ & 220.35 \\
\hline 15.671 & $1.47 \pm 0.01$ & Methyleugenol & $\mathrm{C}_{11} \mathrm{H}_{14} \mathrm{O}_{2}$ & 178.23 \\
\hline 15.899 & $0.27 \pm 0.00$ & Nerolidol & $\mathrm{C}_{15} \mathrm{H}_{26} \mathrm{O}$ & 222.36 \\
\hline 16.5 & $1.03 \pm 0.00$ & (+)-cis-p-Menthane-3,8-diol & $\mathrm{C}_{10} \mathrm{H}_{20} \mathrm{O}_{2}$ & 172.26 \\
\hline 17.185 & $0.38 \pm 0.01$ & Eugenol & $\mathrm{C}_{10} \mathrm{H}_{12} \mathrm{O}_{2}$ & 164.2 \\
\hline 17.27 & $0.35 \pm 0.00$ & p-Menthane-3,8-diol & $\mathrm{C}_{10} \mathrm{H}_{20} \mathrm{O}_{2}$ & 172.26 \\
\hline 18.063 & $0.95 \pm 0.01$ & Citronellic acid & $\mathrm{C}_{10} \mathrm{H}_{18} \mathrm{O}_{2}$ & 170.24 \\
\hline 18.796 & $0.12 \pm 0.00$ & trans-Farnesol & $\mathrm{C}_{15} \mathrm{H}_{26} \mathrm{O}$ & 222.36 \\
\hline 21.632 & $0.12 \pm 0.00$ & Dibutyl phthalate & $\mathrm{C}_{16} \mathrm{H}_{22} \mathrm{O}_{4}$ & 278.34 \\
\hline Others & $1.37 \%$ & & & \\
\hline Total identified & $98.63 \pm 0.24 \%$ & & & \\
\hline
\end{tabular}

*: peaks lower than $0.1 \%$ were not documented. 


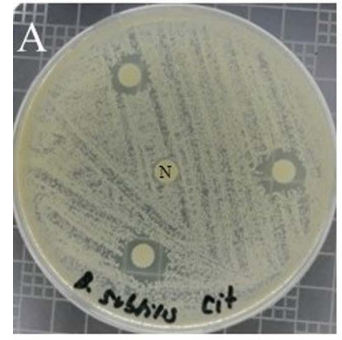

B. subtilis
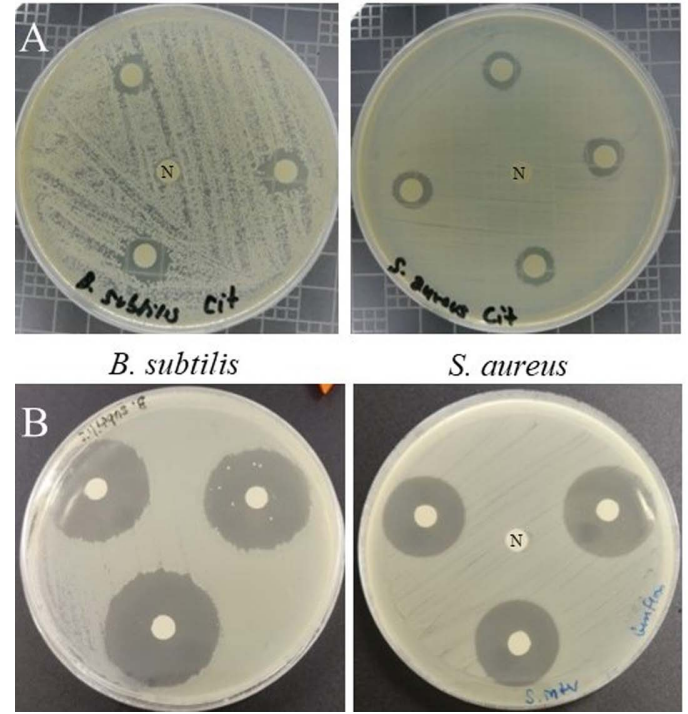

S. aureus

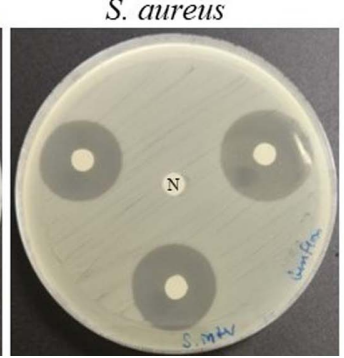

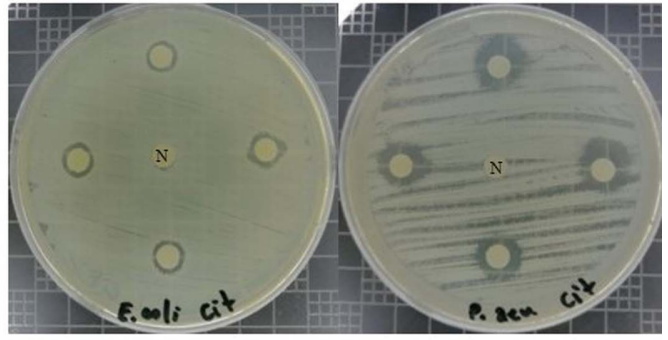

S. intermedius

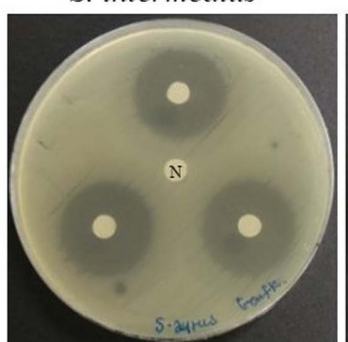

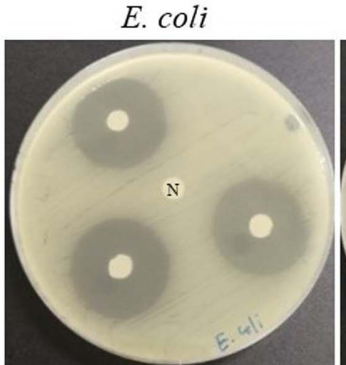

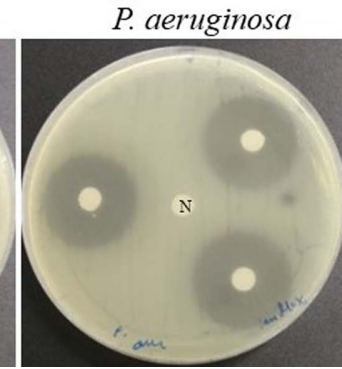

Fig. 2. Inhibition zone caused by Eucalyptus citriodora oil and enrofloxacin on bacteria agar plates. (A) B. subtilis, S. aureus, S. intermedius, E. coli and P. aeruginosa were inhibited by $2 \mu \mathrm{l}$ of E. citriodora oil. (B) positive control; B. subtilis, S. aureus, S. intermedius, $E$. coli and $P$. aeruginosa were inhibited by $4 \mu \mathrm{g} /$ disc of enrofloxacin. (N: negative control of $5 \mu \mathrm{LMSO}$ ).

Table 2. Antimicrobial activities of Eucalyptus citriodora oil against different bacterial strains.

\begin{tabular}{lcc}
\hline \multirow{2}{*}{ Microorganism } & \multicolumn{2}{c}{ Diameters of inhibition zone $(\mathrm{mm})^{*}$} \\
\cline { 2 - 3 } & $\begin{array}{c}\text { E. citriodora oil } \\
(2 \mu \mathrm{l} / \mathrm{disc})\end{array}$ & $\begin{array}{c}\text { Enrofloxacin } \\
(4 \mu \mathrm{g} / \mathrm{disc})\end{array}$ \\
\hline Gram-positive bacteria & & \\
B. subtilis & $11.1 \pm 0.10$ & $31.6 \pm 0.50$ \\
S. aureus & $8.8 \pm 0.25$ & $24.9 \pm 0.81$ \\
S. intermedius & $17.3 \pm 0.75^{\mathrm{b}}$ & $23.3 \pm 1.89$ \\
Gram-negative bacteria & & \\
E. coli & $7.9 \pm 0.10^{\mathrm{a}}$ & $25.7 \pm 0.57$ \\
P. aeruginosa & $10.9 \pm 0.77$ & $25.7 \pm 0.28$ \\
\hline
\end{tabular}

*Includes diameter of disc $(6 \mathrm{~mm})$. Data are means of three replicates $(n=3) \pm S D$. Different letters within a column indicate statistically significant differences $(p<0.05)$ for DIZ.

Table 3. Antibacterial activity of Eucalyptus citriodora oil expressed as minimum inhibitory concentrations (MIC) and minimum bactericidal concentrations (MBC).

\begin{tabular}{lcc}
\hline \multirow{2}{*}{ Bacterial strains } & \multicolumn{2}{c}{ Eucalyptus citriodora oil (\% v/v) } \\
\cline { 2 - 3 } & MIC & MBC \\
\hline B. subtilis & 0.5 & 1.0 \\
S. aureus & 1.0 & 2.0 \\
S. intermedius & 1.0 & 2.0 \\
E. coli & 1.0 & 2.0 \\
P. aeruginosa & 1.0 & 2.0 \\
\hline
\end{tabular}

citriodora oil on the cell of $S$. intermedius and $P$. aeruginosa was examined using SEM. As shown in Fig. 3A and 4A, the untreated cells had normal cellular morphology with an intact cell wall and smooth cell surfaces. In contrast, the $S$. intermedius treated cells had an irregular surface and shrinking, with cell membranes pitted with holes on the surface and losing their normal shape (Figs. 3B-D). For $P$. aeruginosa, after $3 \mathrm{~h}$ and 6 h incubation with $E$. citriodora oil, some cells exhibited uneven distribution, deformed shape and cellular shrinkage (Figs. 4B-C). Moreover, after $16 \mathrm{~h}$ of incubation, cells were more seriously damaged (Fig. 4D) with severe alterations of bacterial morphology.

\section{Effects of $E$. citriodora oil on bacterial protein pattern}

The antibacterial mechanism of $E$. citiodora oil were investigated using analysis of the whole protein patterns of the bacteria. The SDS-PAGE profiles of proteins that had been treated and were untreated with $E$. citriodora oil at a concentration of $1 \mathrm{MIC}$ against $S$. intermedius and $P$. aeruginosa are shown in Figs. $5 \mathrm{~A}$ and $5 \mathrm{~B}$, respectively. The protein bands of treated cells were faded compared to the control. The results of the tested strains after treatment with $E$. citriodora oil showed that the protein bands were smeared and had almost disappeared in all incubation periods, especially the bands 

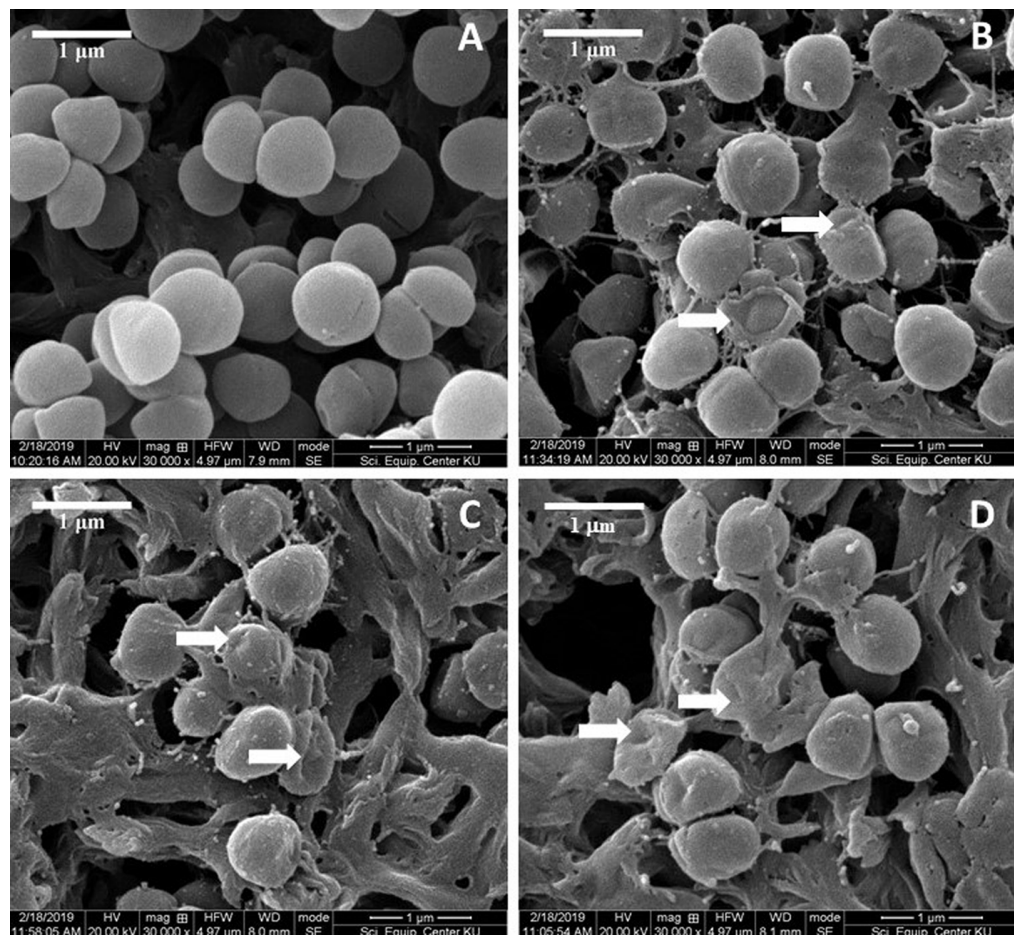

Fig. 3. Effect of Eucalyptus citriodora oil on morphology of S. interemedius using scanning electron microscopy (10,000x). (A) S. intermedius without E. citriodora oil (control); (B-D) S. intermedius treated with E. citriodora oil at minimal inhibitory concentration (MIC) $(1.0 \% \mathrm{v} / \mathrm{v})$ for 3,6 and $16 \mathrm{~h}$, respectively.
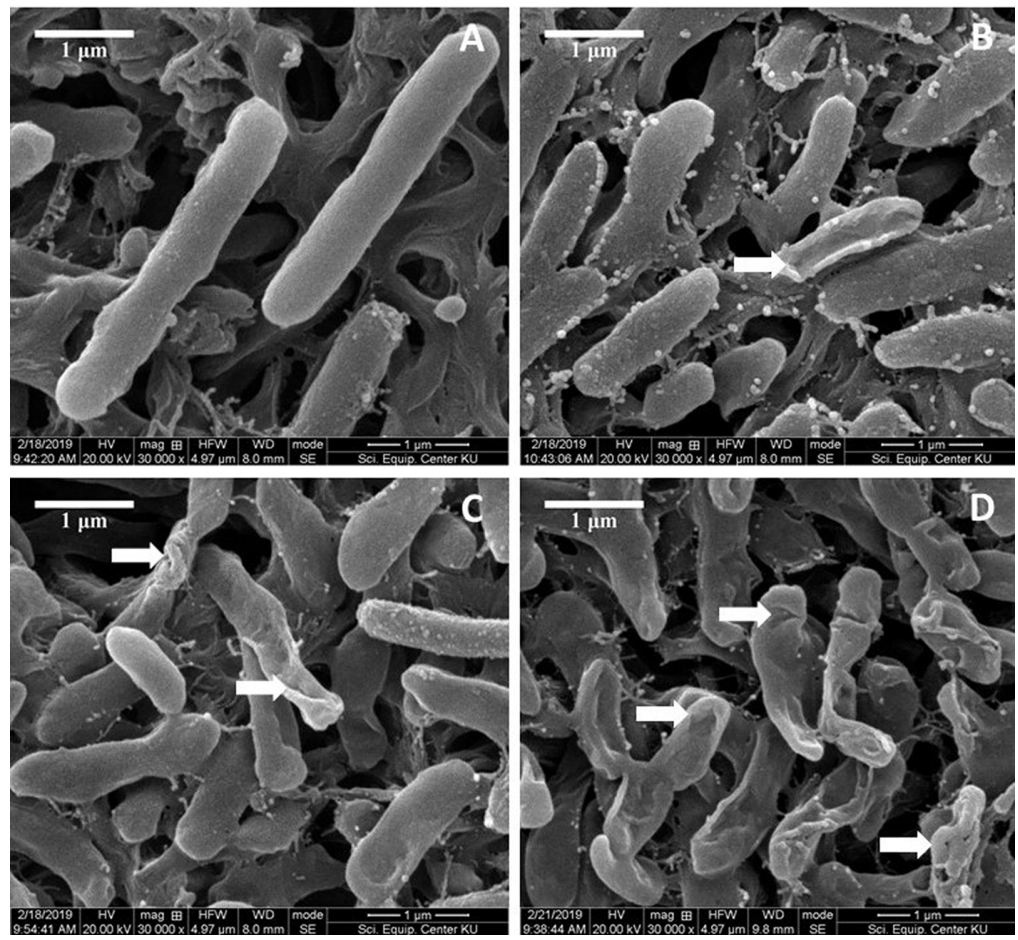

Fig. 4. Effect of Eucalyptus citriodora oil on morphology of $P$. aeruginosa using scanning electron microscopy (10,000x). (A) P. aeruginosa without E. citriodora oil (control); (B-D) P. aeruginosa treated with E. citriodora oil at minimal inhibitory concentration (MIC) $(1.0 \% \mathrm{v} / \mathrm{v})$ for 3,6 and $16 \mathrm{~h}$, respectively. 

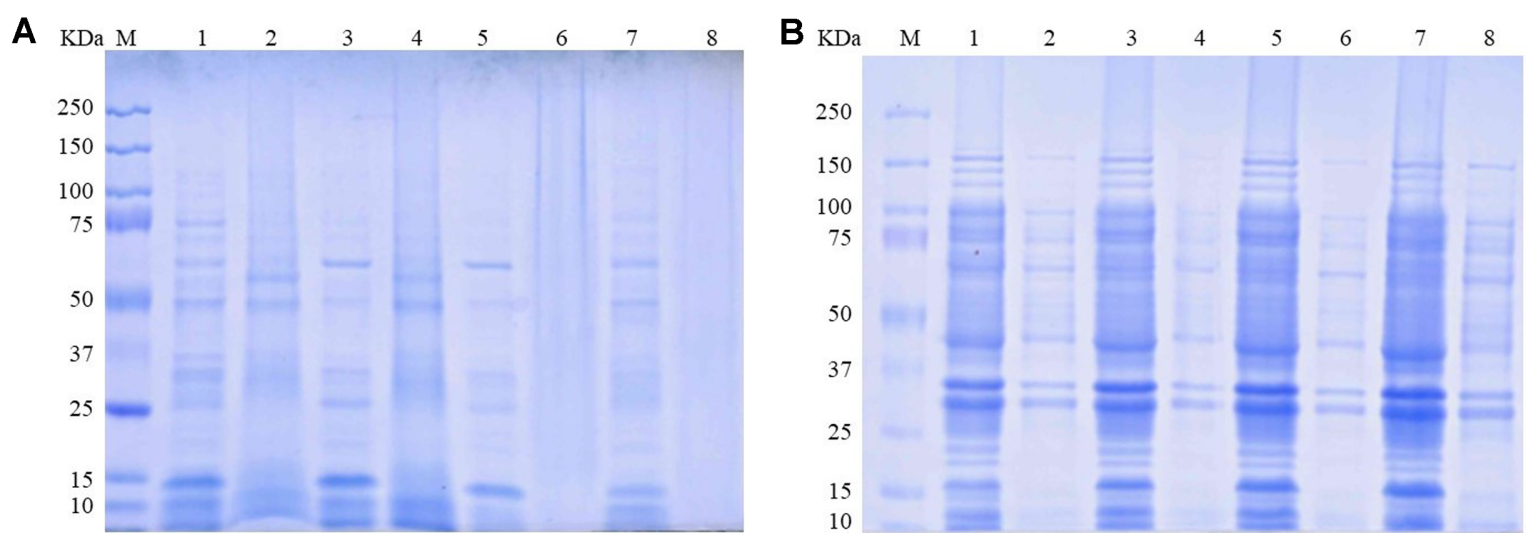

Fig. 5. SDS-PAGE analysis of whole protein profiles from bacteria treated and untreated with Eucalyptus citriodora oil at concentration $1 x$ MIC (1.0\% v/v). (A) S. intermedius, Lane M: marker. Lanes 1, 3, 5, 7: control for 3, 6, 9 and 16 h respectively; Lanes 2, 4, 6, 8: treated samples for 3, 6, 9 and 16 h, respectively. (B) P. aeruginosa, Lane M: marker. Lanes 1, 3, 5, 7: control for 3, 6, 9 and $16 \mathrm{~h}$ respectively; Lanes $2,4,6,8$ : treated samples for $3,6,9$ and $16 \mathrm{~h}$, respectively.

with low molecular weights less than $25 \mathrm{kDa}$. The SDSPAGE results showed the whole protein patterns of both S. intermedius and P. aeruginosa being of low density or to have disappeared.

\section{Discussion}

The antimicrobial properties of essential oil depend on the type of chemical constituents and exhibit different modes of action depending on the main components [7]. The present study indicated that the essential oil from E. citriodora leaves contained citronellal, isopulegol and citronellol as the primary constituents, similarly to the reported of the literatures [14, 19]. Although the major chemical compounds of the oil finding in this study was not similar to other reports, their amounts were different. These are probably affected by many factors such as the cultivation conditions of the plant, geographical location, and extraction techniques [20,21]. The secondary metabolites such as phenolic compound that is found in essential oil with potent anti-microbial activities [14]. The antimicrobial activities of E. citriodora oil against various microorganisms and their activity were qualitatively and quantitatively analyzed using inhibition zone diameters and MIC and MBC values. The MIC and MBC values of essential oil extracted from E. citriodora leaves grown in Egypt against E. coli and S. aureus ranged from 0.06 to $0.2 \mathrm{mg} / \mathrm{ml}$ and 0.12 to $0.41 \mathrm{mg} / \mathrm{ml}$ respectively [12]. E. citriodora oil exhibited anti-MRSA activity with MIC values ranging from 1.0 to $>4.0 \mathrm{mg} / \mathrm{ml}$ [13]. In agreement with our results, the essential oil extracted from E. citriodora leaves cultivated in Thailand had great potential antibacterial activities against all tested strains both gram-positive (B. subtilis, $S$. aureus and $S$. intermedius) and gram-negative (E. coli and $P$. aeruginosa) with $\mathrm{MIC}$ and $\mathrm{MBC}$ values in the range 0.5 to $1.0 \%$ (v/v). The MBC/MIC ratio of E. citriodora oil against selected bacteria was equal to 2.0 , strongly suggesting that $E$. citriodora oil had a bactericidal effect against both gram-negative and gram-positive bacteria [18]. The essential oil extracted from E. citriodora is known to have antimicrobial activity based on the main compounds identified in previous research [11-13]. Various reports have reviewed the antimicrobial activity of E. citriodora oils, few studies have reported on activity against pathogens associated with skin infection in animals [22]. Therefore, the mode of action of the E. citriodora oil against $S$. intermedius and $P$. aeruginosa was investigated. The antibacterial mechanism of action was observed by investigating the morphological alterations using SEM analysis. The SEM results revealed that essential oil induced potential cellular damage which the morphology of $P$. aeruginosa seem to be much more severely damage than $S$. intermedius with time dependent. These supported the possible mechanism being $E$. citriodora oil disrupts the cell membrane and cell wall leading to a decrease in bacterial protein and cellular components resulting in cell death [23-27]. Another 
report suggested that the active compounds in the oil might bind to the cell surface and disrupt the osmotic balance causing leakage of intracellular materials [28]. Corresponding to other results that, eucalyptus oil is more active against gram-positive bacteria than gramnegative bacteria which is attributed to the major chemical constituents [29]. The main chemical compositions; citronellal, isopulegol and citronellol, might be the key chemical constituents which can cause the discharge of gram-negative outer membrane lipopolysaccharide and increase the permeability of the cytoplasmic membrane leading to cell wall lost rigid structure and cell wall components were ruptured [30]. SDS-PAGE is a powerful technique for demonstrating antimicrobial effectivity in bacteria [26, 31]. From our results, there was a reduction in the number of protein bands and a decrease in the whole protein content after the bacterial strains were exposed to essential oil. Taken together, our results indicated that $E$. citriodora oil had an effect on whole cell proteins and could cause bacterial death by destroying cellular proteins or inhibiting protein synthesis [32].

In summary, this study was the first to provide information on the essential oil extracted from E. citriodora leaves cultivated in northern Thailand. The essential oil consisted mainly of citronellal followed by isopulegol and citronellol. It possessed a high antibacterial activity against $S$. intermedius and $P$. aeruginosa as determined by the MIC and MBC values. Through a decrease in bacterial proteins and changing the cell morphology, the main action of E. citriodora oil was suggested to be through affecting the cell wall and cell membrane. These results indicated that $E$. citriodora oil has promise as a natural antibacterial agent with potential to use for development in nanotechnological applications such as nanoemulsion, nanoliposome encapsulation and nanospong in topical hydrogel [33-35]. These applications can be extended to pharmaceutical and cosmeceutical industry.

\section{Acknowledgments}

The authors were very grateful to Sahacogen Green, Co. Ltd. (Thailand), for provided the Eucalyptus leaf samples.

\section{Conflict of Interest}

The authors have no financial conflicts of interest to declare.

\section{References}

1. Hirsch EB, Tam VH. 2010. Impact of multidrug-resistant Pseudomonas aeruginosa infection on patient outcomes. Expert Rev. Pharmacoecon. Outcomes Res. 10: 441-451.

2. Haenni M, Hocquet D, Ponsin C, Cholley P, Guyeux C, Madec JY, et al. 2015. Population structure and antimicrobial susceptibility of Pseudomonas aeruginosa from animal infections in France. BMC Vet. Res. 11: 9.

3. Fernandes MR, Sellera FP, Moura Q, Carvalho MPN, Rosato PN, Cerdeira L, et al. 2018. Zooanthroponotic transmission of drugresistant Pseudomonas aeruginosa, Brazil. Emerg. Infect. Dis. 24: 1160-1162.

4. Bannoehr J, Guardabassi L. 2012. Staphylococcus pseudintermedius in the dog: taxonomy, diagnostics, ecology, epidemiology and pathogenicity. Vet. Dermatol. 23: 253-266.

5. Lainhart W, Yarbrough ML, Burnham CA. 2018. The Brief Case: Staphylococcus intermedius group-look what the dog dragged In. J. Clin. Microbiol. 56: PMID: 29367308.

6. O'Bryan CA, Pendleton SJ, Crandall PG, Ricke SC. 2015. Potential of plant essential oils and their components in animal agriculture - in vitro studies on antibacterial mode of action. Front. Vet. Sci. 2: 35 .

7. Swamy MK, Akhtar MS, Sinniah UR. 2016. Antimicrobial properties of plant essential oils against human pathogens and their mode of action: An updated review. Evid-Based Complement. Alternat. Med. 2016: 3012462.

8. Siramon P, Ohtani Y, Ichiura H. 2013. Chemical composition and antifungal property of eucalyptus camaldulensis leaf oils from Thailand. Rec. Nat. Prod. 7: 49-53.

9. Elaissi A, Rouis Z, Salem NA, Mabrouk S, ben Salem Y, Salah KB, et al. 2012. Chemical composition of 8 eucalyptus species' essential oils and the evaluation of their antibacterial, antifungal and antiviral activities. BMC Complement. Altern. Med. 12: 81.

10. Bardaweel S, Hudaib M, Tawaha K. 2014. Evaluation of antibacterial, antifungal, and anticancer activities of essential oils from six species of Eucalyptus. J. Essent. Oil Bear Plants 17: 1165-1174.

11. Barbosa LC, Filomeno CA, Teixeira RR. 2016. Chemical variability and biological activities of Eucalyptus spp. essential oils. Molecules 21: 12.

12. Salem MZM, Elansary HO, Ali HM, El-Settawy AA, Elshikh MS, Abdel-Salam EM, et al. 2018. Bioactivity of essential oils extracted from Cupressus macrocarpa branchlets and Corymbia citriodora leaves grown in Egypt. BMC Complement Altern. Med. 18: 23.

13. Mulyaningsih S, Sporer F, Reichling J, Wink M. 2011. Antibacterial activity of essential oils from Eucalyptus and of selected components against multidrug-resistant bacterial pathogens. Pharm. Biol. 49: 893-899.

14. Tolba H, Moghrani H, Benelmouffok A, Kellou D, Maachi R. 2015. Essential oil of Algerian Eucalyptus citriodora: Chemical composition, antifungal activity. J. Mycol. Med. 25: e128-e133.

15. Aldoghaim FS, Flematti GR, Hammer KA. 2018. Antimicrobial activity of several cineole-rich western australian eucalyptus 
essential oils. Microorganisms 6: PMID: 30513933.

16. Wayne P. 2015. Methods for Dilution Antimicrobial Susceptibility Tests for Bacteria That Grow Aerobically; Approved Standard. pp. 15-48. Clinical and laboratory Standards Institute.

17. Agizzio AP, Da Cunha M, Carvalho AO, Oliveira MA, Ribeiro SF, Gomes VM. 2006. The antifungal properties of a $2 S$ albuminhomologous protein from passion fruit seeds involve plasma membrane permeabilization and ultrastructural alterations in yeast cells. Plant Sci. 171: 515-522.

18. Haddad M, Zein S, Shahrour H, Krivoruchko E, Chokr A, Kanaan H. 2017. Eucalyptus oil prevents Staphylococcus epidermidis bioilm formation. EJPMR 4: 35-41.

19. Costa AV, Pinheiro PF, de Queiroz VT, Rondelli VM, Marins AK, Valbon WR, et al. 2015. Chemical composition of essential oil from Eucalyptus citriodora leaves and insecticidal activity against Myzus persicae and Frankliniella schultzei. J. Essent. Oil Bear Plants 18: 374-381.

20. Almas I, Innocent E, Machumi F, Kisinza W. 2019. Effect of geographical location on yield and chemical composition of essential oils from three Eucalyptus species growing in Tanzania. Asian J. Tradit. Med. 14: 1-12.

21. Sultana S, Ali M, Ansari SH, Bagri P. 2008. The effect of physical factors on chemical composition of the essential oil of Eucalyptus citriodora Hook. leaves. J. Essent. Oil Bear Plants 11: 69-74.

22. Orchard A, van Vuuren S. 2017. Commercial essential oils as potential antimicrobials to treat skin diseases. Evid-Based Complement. Alternat. Med. 4517971: 1-92.

23. Zhang J, Ye KP, Zhang X, Pan DD, Sun YY, Cao JX. 2016. Antibacterial activity and mechanism of action of black pepper essential oil on meat-borne Escherichia coli. Front. Microbiol. 7: 2094.

24. Li ZH, Cai M, Liu YS, Sun PL, Luo SL. 2019. Antibacterial activity and mechanisms of essential oil from Citrus medica $L$. var. sarcodactylis. Molecules 24: 8 .

25. Lu H, Shao X, Cao J, Ou C, Pan D. 2016. Antimicrobial activity of eucalyptus essential oil against Pseudomonas in vitro and potential application in refrigerated storage of pork meat. Int. J. Food Sci. Tech. 51: 994-1001.
26. Saleem S, Ahmed B, Khan MS, Al-Shaeri M, Musarrat J. 2017. Inhibition of growth and biofilm formation of clinical bacterial isolates by NiO nanoparticles synthesized from Eucalyptus globulus plants. Microb. Pathog. 111: 375-387.

27. Chen C, Liu C-H, Cai J, Zhang W, Qi W-L, Wang Z, et al. 2017. Broad-spectrum antimicrobial activity, chemical composition and mechanism of action of garlic (Allium sativum) extracts. Food Control. 86: 117-125.

28. Zengin H, Baysal AH. 2014. Antibacterial and antioxidant activity of essential oil terpenes against pathogenic and spoilage-forming bacteria and cell structure-activity relationships evaluated by SEM microscopy. Molecules 19: 17773-17798.

29. Winska K, Maczka W, Lyczko J, Grabarczyk M, Czubaszek A, Szumny A. 2019. Essential oils as antimicrobial agents-myth or real alternative? Molecules 24: 1-21.

30. Lertsatitthanakorn P, Taweechaisupapong S, Arunyanart C, Aromdee C, Khunkitti W. 2010. Effect of citronella oil on time kill profile, leakage and morphological changes of Propionibacterium acnes. J. Essent. Oil Res. 22: 270-274.

31. Fei P, Ali M, Gong S, Sun Q, Bi X, Liu S, et al. 2018. Antimicrobial activity and mechanism of action of olive oil polyphenols extract against Cronobacter sakazakii. Food Control. 94: 289-294.

32. Peng L, Kang S, Yin Z, Jia R, Song X, Li L, et al. 2015. Antibacterial activity and mechanism of berberine against Streptococcus agalactiae. Int. J. Clin. Exp. Pathol. 8: 5217-5223.

33. Lin L, Chen W, Li C, Cui H. 2019. Enhancing stability of Eucalyptus citriodora essential oil by solid nanoliposomes encapsulation. Ind. Crops Prod. 140: 111615.

34. Salehi B, Sharifi-Rad J, Quispe C, Llaique H, Villalobos M, Smeriglio A, et al. 2019. Insights into Eucalyptus genus chemical constituents, biological activities and health-promoting effects. Trends Food Sci. Tech. 91: 609-624.

35. Aldawsari HM, Badr-Eldin SM, Labib GS, El-Kamel AH. 2015. Design and formulation of a topical hydrogel integrating lemongrass-loaded nanosponges with an enhanced antifungal effect: in vitro/in vivo evaluation. Int. J. Nanomedicine 10: 893-902. 